\title{
Pathology and first occurrence of the kidney trematode Paratanaisia bragai (Santos, 1934) Freitas, 1959 (Digenea: Eucotylidae) in Phasianus colchicus L., 1758, from Brazil
}

\author{
Delir Corrêa Gomes/ ${ }^{++}$, Rodrigo Caldas Menezes, Rogério Tortelly*, \\ Roberto Magalhães Pinto/ ${ }^{+}++$
}

\begin{abstract}
Laboratório de Helmintos Parasitos de Vertebrados, Departamento de Helmintologia, Instituto Oswaldo Cruz-Fiocruz, Av. Brasil 4365, 21040-900 Rio de Janeiro, RJ, Brasil *Departamento de Patologia, Faculdade de Veterinária, Universidade Federal Fluminense, Niterói, RJ, Brasil
\end{abstract}

The kidney trematode Paratanaisia bragai is reported for the first time parasitizing the ring-necked pheasant (Phasianus colchicus L., 1758) and the pathological alterations associated to the parasitism are referred on the basis of 50 specimens of this bird from backyard flocks in 11 counties of the state of Rio de Janeiro, Brazil after clinical examination, necropsies, and histopathological analysis. The counting of the kidney flukes was based on worms recovered from one of the kidneys, since the other was fixed in 10\% formalin and then routinely processed for histopathological procedures. The prevalence of $\mathrm{P}$. bragai was of $22 \%$, with a mean intensity of 44.3, mean abundance of 9.7, and range of infection of 3-153. Parasitized birds did not present with clinical signs and kidney gross lesions. Microscopic lesions were mild and characterized by dilatation of the renal medullary collecting ducts, occasional flattening of the lining epithelium of the ducts and inflammatory reaction of variable intensity with granulocytes around the ureter branches and medullary collecting ducts. The severity and pattern of the microscopic lesions seem not to be associated to the size of the worm burden and could be related to the mechanic action of the parasites, without traumatism, in despite of the presence of the tegumentar spines in specimens of P. bragai.

Key words: Paratanaisia bragai - Phasianus colchicus - pathology - Brazil

The digenetic trematode Paratanaisia bragai (Santos, 1934) Freitas, 1959 parasitizes the renal medullary collecting ducts and ureters, mostly of Galliformes and Columbiformes hosts and also of Anseriformes and is distributed in the American continent and Phillipines (Maldonado 1941, Travassos et al. 1969, Mena et al. 1986, Fedynich et al. 1996). In Brazil, the species is one of the most prevalent in domestic birds and has already been reported in the kidneys of the pigeon (Columba livia Gmelin, 1798), the ruddy ground-dove (Columbina talpacoti Temminck, 1811), the domestic chicken (Gallus gallus domesticus Linnaeus, 1758), the guinea fowl (Numida meleagris Linnaeus, 1758), the turkey (Meleagris gallopavo Linnaeus, 1758), and also of a wild galliform, the spot-winged wood-quail (Odontophorus capueira Spix, 1825) (Travassos et al. 1969, Costa et al. 1975, Silva et al. 1990, Menezes et al. 2001, Pinto et al. 2004). The intermediate hosts for P. bragai are the terrestrial snails Subulina octona Brugière, 1789 and Leptinaria unilamellata Orbigny, 1835 (Keller \& Araujo 1992, Brandolini et al. 1997).

The parasite has been considered of low pathogenicity, causing mild gross and microscopic lesions in the infected kidneys (Santos 1934, Maldonado 1941, Barretto \& Filho 1942, Menezes et al. 2001, Pinto et al. 2004); nev-

\footnotetext{
${ }^{+}$Corresponding author. E-mail: rmpinto@ioc.fiocruz.br

${ }^{++}$Research fellow CNPq

Received 14 January 2005

Accepted 28 March 2005
}

ertheless, high parasitic burdens and the nature of the hosts, such as the domestic pigeon and the Puerto Rican plain pigeon (Columba inornata wetmorei), can determine the settling of clinical signs that include apathy, loss of weigh, diarrhoea and death (Portugal et al. 1972, Arnizaut et al. 1992).

These controversial data, referred in the few available studies of the pathology induced by this trematode and the fact that after decades of the first report of the species, two new hosts for P. bragai, the guinea fowl and the ruddy ground-dove have been assigned (Menezes et al. 2001, Pinto et al. 2004), indicate that the range of the hosts and the lesions associated to this species are not well established so far.

This investigation reports to data on the prevalence, mean intensity, mean abundance and range of infection of the digenetic trematode P. bragai and to the gross and microscopic lesions associated with this parasite in ringnecked pheasants from backyard flocks in the state of Rio de Janeiro, Brazil, with the establishment of a new host record.

\section{MATERIALS AND METHODS}

Fifty adult specimens of ring-necked pheasants (Phasianus colchicus L., 1758), 25 males, 25 females, weigh 200-1750 g from backyard flocks of 11 localities of the state of Rio de Janeiro, Brazil, were investigated. Localities and number of examined hosts are, respectively: Niterói

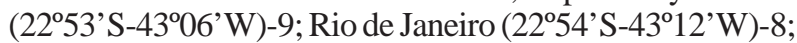
Tanguá (22 $2^{\circ} 73^{\prime}$ S- $\left.42^{\circ} 71^{\prime} \mathrm{W}\right)-9$; São Francisco do Itabapoana ( $21^{\circ} 28^{\prime}$ 'S-41 $08^{\circ}$ 'W)-8; Santo Antônio de Pádua (21 $54^{\circ}$ 'S$\left.42^{\circ} 18^{\prime} \mathrm{W}\right)-2$; Areal $\left(22^{\circ} 14^{\prime} \mathrm{S}-43^{\circ} 65^{\prime} \mathrm{W}\right)-3$; Petrópolis 
( $22^{\circ} 30^{\prime}$ S- $\left.43^{\circ} 10^{\prime} \mathrm{W}\right)-2$; São José do Vale do Rio Preto

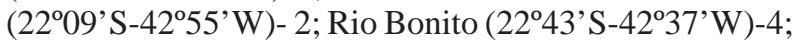
Engenheiro Paulo de Frontin (22 $32^{\prime}$ S- $43^{\circ} 40^{\prime} \mathrm{W}$ )-2; Laje do Muriaé $\left(21^{\circ} 12^{\prime} \mathrm{S}-42^{\circ} 07^{\prime} \mathrm{W}\right)-1$. After individual clinical evaluation birds were killed and submitted to necropsy, according to the technique of Zander et al. (1997).

The kidneys and ureters were removed and dissected with the aid of a scissor, in separated Petri dishes containing $0.85 \% \mathrm{NaCl}$ solution. Trematodes were collected with the aid of thin brushes, (no. 00), rinsed in the same solution, fixed with $\mathrm{AFA}$ (alcohol $70^{\circ} \mathrm{GL}, 93 \mathrm{ml}$; formaldehyde, $5 \mathrm{ml}$; acetic acid, $2 \mathrm{ml}$ ) and counted under a stereoscope microscope. Counting of the kidney flukes was performed in one kidney. The other was immediately fixed in $10 \%$ formalin and then routinely processed (Behmer et al. 1976) for parafin embedding. Five micrometers thick sections were stained with hematoxylin and eosin (HE). Values referring to prevalence, mean intensity, mean abundance and range of infection are in accordance with Bush et al. (1997).

Trematodes were stained with alcoholic chloride Langeron's carmine by the regressive process, according to Amato (1985). Some specimens were maintained as wet material and other preserved in Canada balsam and deposited in the Helminthological Collection of the Oswaldo Cruz Institute (CHIOC) numbers 35206-35215 (wet material); 36328 a-b, 36329, 36330 a, 36331, 36332 a-b, 36333, 36334 , and 36335 (whole mounts); slides 36330 b, $36332 \mathrm{c}$, 36336 refer to histological sections. Classification of the trematodes to the specific level is in accordance with Travassos et al. (1969).

The development of this research has been authorized by the Committee of Ethics for the Use of Animals (CEUA/Fiocruz) no. P0095-01.

\section{RESULTS}

The prevalence of $P$. bragai was of $22 \%$, with a mean intensity of 44.3, mean abundance of 9.7 and range of infection of 3-153, in a total amount of 487 worms. Trematodes were collected from the medullary collecting ducts (Figs 1, 2, 4), ureters and their branches. The trematodes were present in six out of the eleven investigated localities (Table I).
Parasitized birds did not present with clinical signs. The gross lesions in the kidney and ureters of parasitized birds were absent. The microscopic lesions were represented by very dilated medullary collecting ducts (Figs 1 , 2). In the bird with the highest parasite burden (153), the worms, mostly immature, were associated with the dilata-

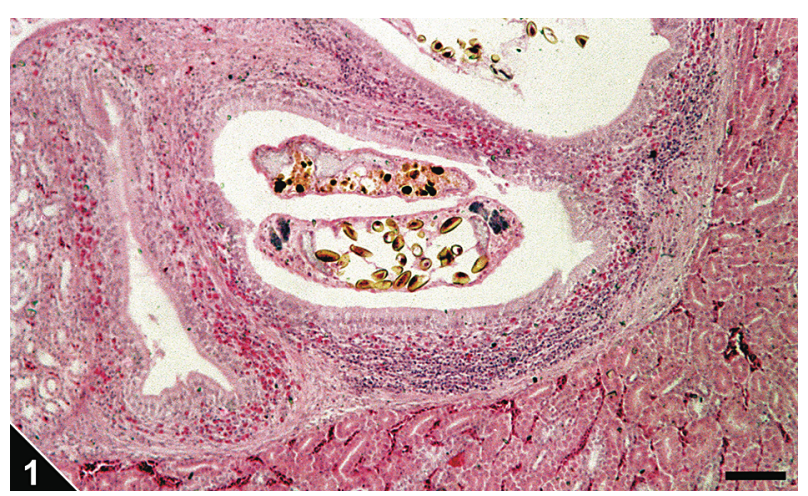

Fig. 1: cross-section of the kidney of Phasianus colchicus showing specimens of Paratanaisia bragai in very dilated medullary collecting ducts and a severe inflammatory reaction around them composed by granulocytes together with lymphatic infiltrations, normally present in this region. Bar $=0.16 \mathrm{~mm}$.

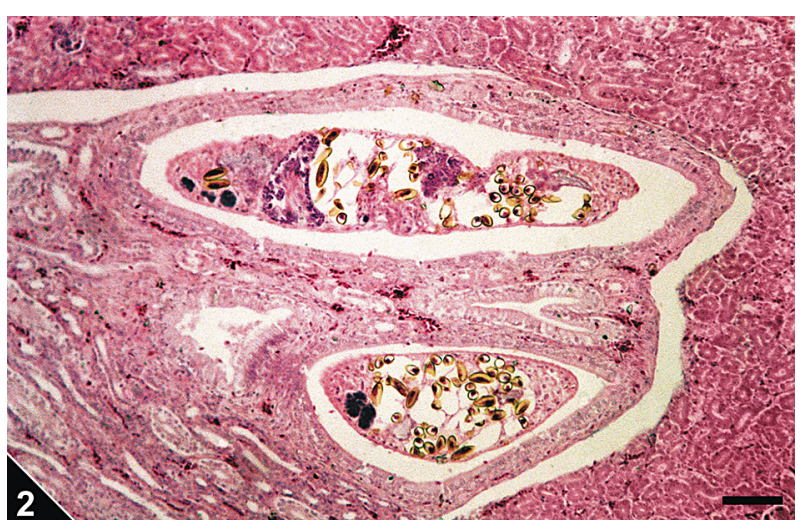

Fig. 2: cross-section of the kidney of Phasianus colchicus showing specimens of Paratanaisia bragai in very dilated medullary collecting ducts and absence of inflammatory reaction. Bar $=0.15$ $\mathrm{mm}$.

\section{TABLE I}

Data on Paratanaisia bragai parasitizing ring-necked pheasants from backyard flocks of the eleven investigated localities of the state of Rio de Janeiro, Brazil

\begin{tabular}{lcccc}
\hline Localities & Parasitized/examined ${ }^{a}$ & $\%$ & Mean intensity of infection & Range of infection \\
\hline Niterói & $6 / 9$ & 66.6 & 61.7 & $8-153$ \\
Rio de Janeiro & $0 / 8$ & 0 & 0 & 0 \\
Tanguá & $0 / 9$ & 0 & 0 & 0 \\
São Francisco do Itabapoana & $1 / 8$ & 12.5 & 85 & 85 \\
Santo Antônio de Pádua & $0 / 2$ & 0 & 0 & 0 \\
Areal & $0 / 3$ & 0 & 0 & 0 \\
Petrópolis & $1 / 2$ & 50 & 3 & 3 \\
São José do Vale do Rio Preto & $0 / 2$ & 0 & 0 \\
Rio Bonito & $1 / 4$ & 25 & 19 & 4 \\
Engenheiro Paulo de Frontin & $1 / 2$ & 50 & 6 & 19 \\
Laje do Muriaé & $1 / 1$ & 100 & & 6
\end{tabular}

$a$ : total number of examined $=50$ 
tion of the medullary collecting ducts and flattening of the lining epithelium of these structures were present (Fig. 4). In a few of the parasitized birds, an inflammatory reaction of varied intensity with granulocytes around the medullary collecting ducts and ureter branches (Figs 1, 3) together with lymphatic infiltrations, commonly present, were observed. This reaction was severe in two of the pheasants with intensities of infection of 10 and 85 worms, respectively, in one of the kidneys, showing to be more intense around the branches of the ureter (Fig. 3) and even absent in some areas of the medullary tissue with parasitized collecting ducts (Fig. 2). In one of the birds, with an intensity of infection of 3 worms this reaction was discrete, whereas in other infected birds in which values of the mean intensity and range of infection were of 65.2 and 4-153, respectively, was absent (Fig. 4).

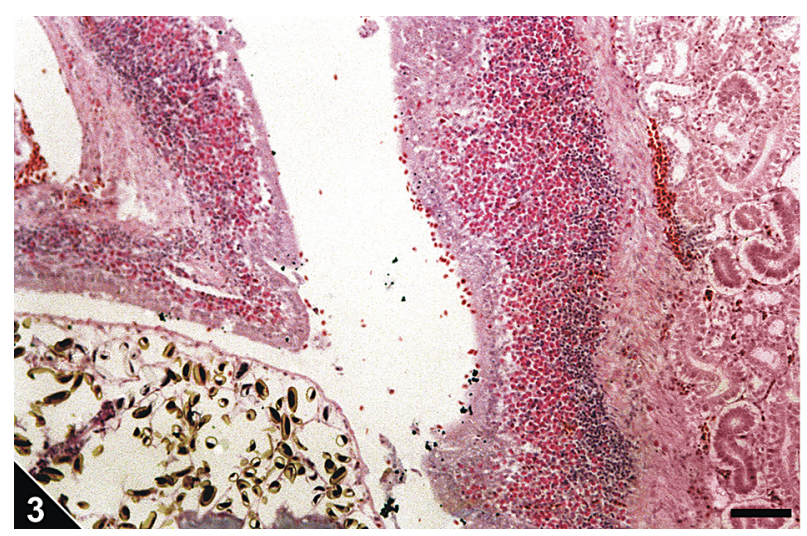

Fig. 3: severe inflammatory reaction around a ureter branch parasitized by Paratanaisia bragai. $\mathrm{Bar}=0.20 \mathrm{~mm}$.

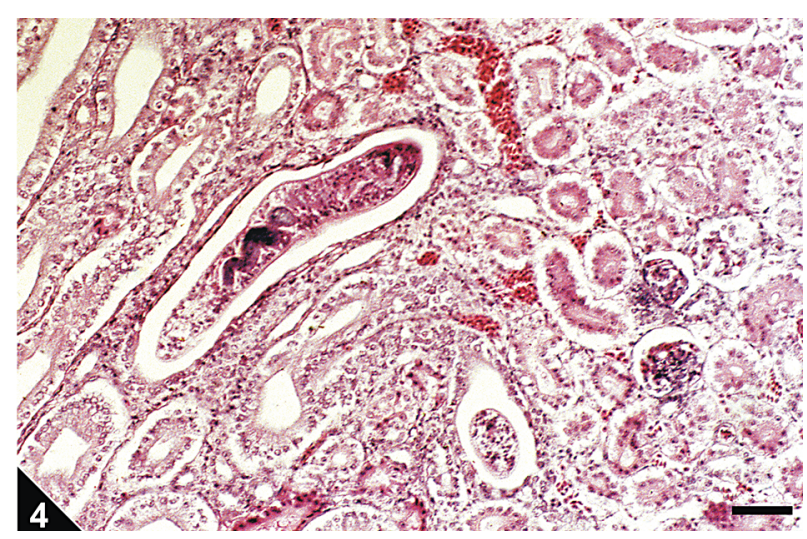

Fig. 4: cross-section of the kidney of Phasianus colchicus showing immature specimens of Paratanaisia bragai in very dilated medullary collecting ducts presenting flatenning of lining epithelial cells. No inflammatory reaction in the adjacent renal tissue is observed. $\mathrm{Bar}=0.14 \mathrm{~mm}$.

\section{DISCUSSION}

The trematode $P$. bragai, for the first time referred in pheasants, presented, in the same study area, a lower prevalence than that reported by Silva et al. (1990) in domestic pigeons and by Menezes et al. (2001) in guinea fowls but higher when compared to the findings of Pinto et al. (2004) in ruddy ground-doves. The results presently obtained and previous data, indicate that $P$. bragai is of common occurrence in domestic birds in the state of Rio de Janeiro and that the ring-necked pheasant is a susceptible host for the parasite under natural conditions. Taking into account the low specificity of this helminth, the maintainance of pheasants together with other susceptible domestic birds can promote helminth cross-infections and the spreading of the renal monostomosis due to $P$. bragai. Wild birds such as the ruddy ground-dove (Columbina talpacoti), that according to Pinto et al. (2004) can be infected with high worm burdens of $P$. bragai, are commonly in close contact with domestic galliforms sharing food, and thus, probably acting as reservoirs and carriers of pathogenic agents to these hosts.

Morphological measurements in specimens of $P$. bragai recovered from the ring-necked pheasants are in accordance to those referred for this parasite from other hosts (Santos 1934, Stunkard 1945, Freitas 1951, Menezes et al. 2001, Pinto et al. 2004).

Taking into account the mean infections observed, $P$. bragai showed to be of low pathogenicity for the ringnecked pheasants, determining only mild microscopic lesions, similar to those reported in other hosts (Santos 1934, Maldonado 1941, Barretto \& Filho 1942, Menezes et al. 2001, Pinto et al. 2004). Nevertheless, Arnizaut et al. (1992) and Portugal et al. (1972) refer to clinical signs, renal gross lesions and death in Puerto Rican plain pigeons and domestic pigeons, respectively, associated to very high worm burdens of $P$. bragai; however, the severity and patterns of microscopic lesions seem not to be related to the size of the worm burden, in accordance with Pinto et al. (2004). Some ring-necked pheasants, with low worm burdens, presented either severe or mild inflammatory reaction, whereas in birds with higher parasite loads, this reaction was absent. The site of infection, size of the parasites (predominance of either adult or immature worms), parasite strain and host could determine the severity of the lesions. The mild and rare lesions observed in the lining epithelium of the parasitized medullary collecting ducts seem to be related to the mechanical action of the parasite with no signs of traumatic action in despite of the tegumentary spines present in the specimens of $P$. bragai.

\section{ACKNOWLEDGEMENTS}

To Bruno Eschenazi Silveira, Laboratório de Imagens, Instituto Oswaldo Cruz, for technical assistance regarding the figures.

\section{REFERENCES}

Amato JFR 1985. Manual de Técnicas para a Preparação de Coleções Zoológicas. 8. Platelmintos (Temnocefálidos, Trematódeos,Cestóides, Cestodários) e Acantocéfalos, Sociedade Brasileira de Zoologia, São Paulo, 11 pp.

Arnizaut AB, Hayes GD, Olsen H, Torres JS, Ruiz C, PérezRivera R 1992. An epizootic of Tanaisia bragai in a captive population of Puerto Rican plain pigeon (Columba inornata wetmorei). Ann N Y Acad Sci 653: 202-205.

Barretto JF, Filho AM 1942. Primeiras Observações sobre a Presença de "Tamerlanea Bragai" (Violantino Santos, 
1934) nos Rins de Meleagris gallopavo domestica, Serviço de Informação Agrícola, Ministério da Agricultura, Departamento Nacional de Produção Animal, Instituto de Biologia Animal, Rio de Janeiro, 3 pp.

Behmer OA, Tolosa EMC, Freitas-Neto AG 1976. Manual de Técnicas para Histologia Normal e Patológica, Edart, São Paulo, 256 pp.

Brandolini SVPB, Amato SB, Pereira AA 1997. Relacionamento de Tanaisia bragai (Digenea, Eucotylidae) e seu hospedeiro intermediário, Subulina octona (Gastropoda, Subulinidae) sob condições experimentais. Parasitol Día 21: 109-113.

Bush AO, Lafferty KD, Lotz JM Schostak AW 1997. Parasitology meets ecology on its own terms: Margolis et al. revisited. J Parasitol 83: 575-583.

Costa HMA, Leite ACR, Guimarães MP, Lima WS 1986. Distribuição de helmintos parasitos dos animais domésticos no Brasil. Arq Bras Med Vet Zootec 38: 465-579.

Costa JO, Guimarães MP, Grisi L Barros GC 1975. Helmintos parasitos de Gallus gallus domesticus (L.) no litoral sul do Espírito Santo. Arq Esc Vet UFMG 27: 45-46.

Fedynich AM, Pence DB, Bergan JF 1996. Helminth community structure and pattern in sympatric populations of blackbellied and fulvous whistling-ducks. Can J Zool 74: 22192225.

Freitas JFT 1951. Revisão da família Eucotylidae Skrjabin, 1924 (Trematoda). Mem Inst Oswaldo Cruz 49: 33-123.

Keller DG, Araujo JLB 1992. Ciclo evolutivo de Paratanaisia bragai (Santos, 1934) (Trematoda, Eucotylidae) com novo hospedeiro intermediário no Brasil: Leptinaria unilamellata (D’Orbigny, 1835) (Gastropoda, Pulmonata, Subulinidae) em condições de laboratório. Rev Bras Parasitol Vet 1/2: 89-92.

Maldonado JF 1941. Tamerlanea bragai, a parasite of pigeons in Puerto Rico. J Parasitol 27: 91.
Mena R, Mendez M, Aguirre R 1986. Presencia en Cuba de la trematodiasis renal de la paloma doméstica (Columba livia domestica) por Tamerlania bragai Dos Santos, 1934. Rev Cubana Cienc Vet 17: 25-28.

Menezes RC, Mattos-Júnior DG, Tortelly R, Muniz-Pereira LC, Pinto RM, Gomes DC 2001. Trematodes of free range reared guinea fowls (Numida meleagris Linnaeus, 1758) in the state of Rio de Janeiro, Brazil: morphology and pathology. Avian Pathol 30: 209-214.

Pinto RM, Menezes RC Tortelly R 2004. Systematic and pathologic study of Paratanaisia bragai (Santos, 1934) Freitas, 1959 (Digenea, Eucotylidae) in ruddy ground dove, Columbina talpacoti (Temminck, 1811). Arq Bras Med Vet Zootec 56: 472-479.

Portugal MASC, Oliveira GF, Fenerich FL, Cappellaro CEMPM, Chiarelli V 1972. Ocorrência de Paratanaisia bragai (Santos, 1934) Freitas, 1959 (Trematoda, Eucotylidae), em pomba doméstica (Columba livia domestica). Arq Inst Biol 39: 189-194.

Santos V 1934. Monostomose renal das aves domésticas. Rev Dep Nac Prod Animal 1: 203-211.

Silva CC, Mattos-Júnior DG, Ramirez PM 1990. Helmintos parasitos de Columba livia $(\mathrm{Gm})$ no município de São Gonçalo, Rio de Janeiro. Arq Bras Med Vet Zootec 42: 391394.

Stunkard HW 1945. The morphology of Tamerlania bragai Dos Santos, 1934. J Parasitol 31: 301-305.

Travassos L, Freitas JFT, Kohn A 1969. Trematódeos do Brasil. Mem Inst Oswaldo Cruz 67: 1-886.

Zander DV, Bermudez AJ, Mallinson ET 1997. Principles of disease prevention: diagnosis and Control. In BW Calneck, HJ Barnes, CW Beard, LR McDougald, YM Saif (eds), Diseases of Poultry, Iowa State University Press, Ames, p. 3-45. 